\title{
Clinical presentation and cytokine production abnormalities in a cohort of patients carrying NLRP12 gene variants
}

\author{
Antonella Insalaco ${ }^{1}$, Luigi Raganelli ${ }^{1}$, Manuela Pardeo ${ }^{1}$, Virginia Messia ${ }^{1 *}$, Denise Pires Marafon?', \\ Francesca Romana Lepri ${ }^{2}$, Elisa Pisaneschi ${ }^{2}$, Claudia Bracaglia ${ }^{1}$, Lidia Melii ${ }^{1}$ Valeria Gerloni ${ }^{3}$, Rebecca Nicolai ${ }^{1}$, \\ Elisabetta Cortis ${ }^{4}$, Fabrizio De Benedetti ${ }^{1}$, Giusi Prencipe ${ }^{1}$
}

From 21st European Pediatric Rheumatology (PReS) Congress

Belgrade, Serbia. 17-21 September 2014

\section{Introduction}

The NLRP12 related autoinflammatory disorder (NLRP12-RD) is a rare autosomal dominant disease, caused by mutations in the NLRP12 gene. Clinical manifestations are extremely heterogeneous.At present,only few cases have been described.Patients occasionally required treatment with steroids and NSAIDS for short periods. Treatment with Anakinra induced an initial good response,that appears to decrease over time.

\section{Objectives}

To describe clinical features and inflammatory response of a cohort of patients carrying different NLRP12 variants, some of which not yet described as being associated with NLRP12-RD.

\section{Methods}

Twelve caucasian patients( 6 males)carrying NLRP12 variants were identified. Blood samples obtained from 9/12 NLRP12 patients and from 7 active Juvenile idiopathic arthritis(JIA) patients were stimulated ex vivo with $1 \mathrm{mg} / \mathrm{ml}$ of Zymosan for 22h. Whole blood RNA analysis was also performed, using a human immune array(TaqMan ${ }^{\circledR}$ Human Immune Array from Applied Biosystems), containing 92 genes typically involved in the immune response.

\section{Results}

The median age at symptoms onset was 11,4 months (IQR 4, 6-35, 2) and the median of disease duration

'Division of Rheumatology, Department of Pediatric Medicine, IRCCS Ospedale Pediatrico Bambino Gesù, Italy

Full list of author information is available at the end of the article was 6,8 years(IQR 4,1-11). Sequencing of NLRP12 gene in the 12 patients revealed 5 heterozygous mutations: F402L $(n=6), G 448 A(n=1), H 304 Y(n=1), R 1030 G(n=1)$ and $\operatorname{G3} \mathrm{V}(\mathrm{n}=1)$. Two patients were homozygous for NLRP12 variants: F402L and G39V. In 6/12 variants of NLRP3 were also found: Q703K $(\mathrm{n}=4)$ and $\operatorname{V198M}(\mathrm{n}=2)$. All patients had symptoms consistent with a recurrent inflammatory syndrome: $11 / 12$ presented recurrent episodes of skin lesions, 11/12 arthralgia, 10/12 recurrent fever episodes, $8 / 12$ arthritis,10/12 headache, $11 / 12$ fatigue, $5 / 12$ conjunctivitis, $7 / 12$ recurrent abdominal pain and lymphadenopathy,5/12 oral aphthosis, 4/12 thoracic pain and 2/12 sensorineural deafness. During the attacks $5 / 12$ patients showed increased acute phase reactants.In $5 / 12$ patients anakinra was administered because of the severity of phenotype and the persistence of elevated acute phase reactants.In 2 of these 5 patients lack of efficacy led withdrawal of anakinra and introduction of tocilizumab with good response.In vitro cytokine release studies, performed in 9 patients,showed that the production of IL-6 and TNF-a was significantly higher in patients carrying the NLRP12 variants compared to patients with JIA (IL$6: 2841 \pm 1682 \mathrm{ng} / \mathrm{ml}$ and $1496 \pm 982.4 \mathrm{ng} / \mathrm{ml}$ versus 498.8 $\pm 338.7 \mathrm{ng} / \mathrm{ml}$ and $226.6 \pm 111.8 \mathrm{ng} / \mathrm{ml}$ respectively; $\mathrm{p}=0.0002$ and $\mathrm{p}=0.007$ ) and even higher in homozygous patients;no significant difference in IL-1 $\beta$ production was found $(2134 \pm 1026 \mathrm{ng} / \mathrm{ml}$ versus $1527 \pm 930.3 \mathrm{ng} / \mathrm{ml}$, $\mathrm{p}=0.29$ ). Whole blood RNA samples collected from 5 NLRP12 patients were compared to 6 whole blood RNA samples collected from healthy controls comparable for age.At basal level,we did not find significant differences in the expression of 92 genes evaluated. 


\section{Conclusion}

Our data in vitro and in vivo suggest that these NLRP12 variants are pathogenic. The role played by the concomitant presence of the NLRP3 variants remains to be clarified,though an effect in modifying the disease phenotype cannot be excluded. Our data also confirm the clinical and functional heterogeneity of NLRP12 related disorder, a condition often misunderstood.Furthermore, although the small number of patients treated,our data suggest that inhibition of IL-6 may be effective in NLRP12-related disorder.

\section{Disclosure of interest}

None declared.

\section{Authors' details}

${ }^{1}$ Division of Rheumatology, Department of Pediatric Medicine, IRCCS Ospedale Pediatrico Bambino Gesù, Italy. ${ }^{2}$ Cytogenetics, IRCCS Ospedale Pediatrico Bambino Gesù, Rome, Italy. ${ }^{3}$ Pediatric Rheumatology Unit, Department of Rheumatology, Istituto Ortopedico G.Pini University of Milan, Milan, Italy. ${ }^{4}$ Division of Pediatric, Santa Maria della Stella Hospital, Orvieto, taly

Published: 17 September 2014

\section{doi:10.1186/1546-0096-12-S1-P71}

Cite this article as: Insalaco et al:: Clinical presentation and cytokine production abnormalities in a cohort of patients carrying NLRP12 gene variants. Pediatric Rheumatology 2014 12(Suppl 1):P71.

Submit your next manuscript to BioMed Central and take full advantage of:

- Convenient online submission

- Thorough peer review

- No space constraints or color figure charges

- Immediate publication on acceptance

- Inclusion in PubMed, CAS, Scopus and Google Scholar

- Research which is freely available for redistribution

Submit your manuscript at www.biomedcentral.com/submit 